\title{
IMPLEMENTATION OF INTEGRATED TERRITORIAL INVESTMENTS IN POLAND - RATIONALE, RESULTS, AND RECOMMENDATIONS
}

\author{
Dagmara Kociuba \\ Department of Spatial Policy and Planning, Maria Curie-Skłodowska University in Lublin, Poland
}

Manuscript received: June 22, 2018

Revised version: October 29, 2018

\begin{abstract}
Kociuba D., 2018. Implementation of integrated territorial investments in Poland - rationale, results, and recommendations. Quaestiones Geographicae 37(4), Bogucki Wydawnictwo Naukowe, Poznań, pp. 81-98. 4 tables, 5 figs.

ABSTRACT: The objective of the article is the presentation of the practical aspect of implementation of one of the new tools of Cohesion Policy 2014-2020, namely Integrated Territorial Investments (ITIs) in functional urban areas (FUAs) in Poland. In the context of general rules of implementation of the instrument resulting from statutory provisions and ministry guidelines, the article presents the practical aspects of that process, including the establishment of an ITI union, the delimitation of the support area, development of the ITI strategy, and thematic and substantive scope of projects designated for financing. Moreover, the paper presents the degree of advancement of the implementation of ITIs as at the end of May 2018. The analyses permitted the identification of areas that will receive the most support and development of a catalogue of predominant investments and their beneficiaries, as well as a level of contracting of dedicated allocation of ITIs in particular FUAs. Finally, the article includes recommendations of what should be changed in the institutional, governance, and strategic programming aspect for the implementation of ITIs in the future perspective to be more effective.
\end{abstract}

KEY wORDS: Integrated Territorial Investments (ITIs), ITI implementation, Cohesion Policy 2014-2020, functional urban areas (FUAs), Poland

Corresponding author: Department of Spatial Policy and Planning, Maria Curie-Sktodowska University in Lublin, Al. Kraśnicka 2 cd, 20-718 Lublin, Poland, e-mail: dagmara.kociuba@poczta.umcs.lublin.pl

\section{Introduction}

The current period of programming and implementation of the EU Cohesion Policy is closely related to the negative experiences of EU countries in the scope of distribution of resources and introduction of tools aimed at stimulating the development of countries and regions which brought no expected results in practice, i.e. did not lead to a permanent increase in the rate of economic growth at the place of intervention (Rodríguez-Pose, Fratesi 2004; Gorzelak 2014). Therefore, in the first decade of the 21st century, activities aimed at orienting the policy of distribution of resources from the ineffective all-size-fits-all to territorially oriented were intensified (Storper 1997; Pietrzyk 2004; Tödtling, Trippl 2005). A new paradigm of the regional development policy, promoted from the end of the 1990s by OECD (2001), was recognised to be competitiveness and economic cohesion built based on the specific territorial potential of a given region (territorial capital) and "three key principles: endogenous development (aimed at enhancing territorial units' own opportunities for expansion); sustainable development (aimed at reconciling the objectives of economic efficiency, social cohesion and ecological balance) and 
more accountable governance" (OECD 2001: 27). This led to clarification of the place-based concept proposed by Prof. Fabrizio Barca in the independent report A place-based approach to meeting European Union challenges and expectations (2009) and emphasised in the report of OECD Regions matter: Economic recovery, innovation and sustainable growth (2009). They specify the unit of intervention as a place or region defined not in the aspect of administrative boundaries, but challenges, potentials, and development barriers with simultaneous existence of functional-spatial relations and concentration of population flow. Moreover, the concept assumes that the effectiveness of interventions is related to moving away from the sectoral approach and support of the poorest countries/regions, and should focus on support of endogenic potentials of a given 'place' in a long-term period through integration of public activities in the spatial dimension, targeted intersectoral interventions, and well developed system of multi-level governance. The activities are aimed at support of obtaining competitive advantage by regions and countries (Barca 2009; OECD 2009).

Such an approach was adopted in the assumptions of the strategic development of the EU. The theses were reflected in documents at the EU level, i.e. the Lisbon Treaty (2007, enacted in 2009) introducing the territorial dimension to the EU policy, Europe 2020 Strategy (2010), and Territorial Agenda of the European Union 2020 (2011). These documents promote a placebased, integrated approach to the development policy for the purpose of increasing the efficiency of activities on all levels of authority in the development of synergies between different types of interventions (Barca et al. 2012; Mendez 2012; McCann, Ortega-Argilés 2013; Markowski 2013; Szafranek 2015). It was also determined that particular support should be granted to the intensive development of areas which have a chance for effective participation in global competition (Farole et al. 2011; OECD 2011). The 'driving forces' were determined to be cities and their functional areas, with designated key role in the development of regions and building their territorial cohesion (the Leipzig Charter 2007; EU Territorial Agenda 2020 (2011); Urban Agenda for the EU 2016).

In this trend, the place-based approach and multi-level governance with its strong adaptation abilities have become the most important elements of implementation of the development policy in the 2014-2020 programming period (Szlachta, Zaucha 2012; Mendez 2013; van der Zwet et al. 2014). The theses translated into binding solutions in the sphere of financing of activities in the scope of the Cohesion Policy 2014-2020 conducted in the Common Strategic Framework (CEC 2012). Key issues in the implementation of the provisions include on the one hand moving away from the perception of the support area in the context of administrative boundaries, and on the other hand strengthening of mechanisms facilitating territorial coordination of interventions. The implementation of the assumptions is supported by the introduction of two new tools. In the strategic-planning aspect they are functional areas, including functional urban areas (FUA), and in the financial-programming-governance aspect Integrated Territorial Investments (ITIs) (Churski et al. 2017; Kociuba 2017). Due to the possibility of ITI implementation, EU countries faced new challenges in the scope of territorial governance of functional areas of cities, and possibilities of implementation of common integrated projects.

The objective of the paper is to present the practical aspect of the implementation of Integrated Territorial Investments as an instrument of territorial development - in the governance and programming, as well as the financial dimension. The study focused on the analysis and assessment of the effect of ITI unions on territorial governance in functional urban areas. The works involved the analysis of the actual cooperation of local government units (LGUs) in the scope of functioning partnerships, with particular consideration of the process of establishment of ITI unions and their effect on the delimitation of the support area and scope of delegation of tasks of the ITI union in the implementation of regional operational programmes (ROPs). On the other hand, it focused on the implementation of projects adopted in ITI strategies corresponding with selected thematic objectives (TOs) and investment priorities (IPs). The analysis covered the financial, thematic, and substantive scope of projects and directions of intervention, as well as the degree of implementation of ITIs in FUAs (the state as at the end of May 2018). The analyses permitted the designation of areas that will receive the greatest support and the development of a catalogue of predominant 
investments and their beneficiaries. The paper also includes recommendations of what should be changed in the institutional, governance, and strategic programming aspect for the future implementation of ITIs to be more effective and not lead to the dispersal of resources.

The study was particularly based on a review of source materials concerning ITI implementation in functional areas. They include: ITI strategies of 26 functional areas, i.e. all FUAs of voivodeship centres $^{1}$ and those among regional and subregional centres ${ }^{2}$ which obtained financing under restricted call for proposals in the framework of ROPs, 16 regional operational programmes and their detailed descriptions of priority axes regarding the implementation of measures and sub-measures related to the ITI, ministry guidelines, and materials obtained directly in ITI offices and on the websites of the Ministry of Investment and Economic Development (https://www.funduszeeuropejskie.gov.pl).

\section{ITIs in the EU Cohesion Policy 2014- 2020}

\section{Rationale}

The EU Cohesion Policy 2014-2020 is aimed at the support of endogenous potential of a given region and countries perceived in terms of functionality instead of existence of administrative borders, both in the aspect of territorialisation of intervention and support of rules of territorial governance (Camagni, Capello 2015; Binek et al. 2016; Kaczmarek, Kociuba 2017). The approach is strongly reflected in the Europe 2020 Strategy (2010) which requires policy makers to consider how different aspects of smart, sustainable, and inclusive growth are interrelated. As a

ITI strategies for: Białystok FUA, Bydgoszcz-Toruń FUA, Gdańsk-Gdynia-Sopot (Tricity) FUA, Gorzów Wielkopolski FUA, Central Subregion (Katowice) FUA, Kielce FUA, Kraków FUA, Lublin FUA, Łódź FUA, Olsztyn FUA, Opole FUA, Poznań FUA, Rzeszów FUA, Szczecin FUA, Warszawa FUA, Wrocław FUA, Zielona Góra FUA

2 ITI strategies for: Wałbrzych FUA and Jelenia Góra FUA, Kalisz-Ostrów FUA, Elbląg FUA, Ełk FUA, Koszalin-Kołobrzeg-Białogard) FUA, and FUA of Bielsko-Biała - South Subregion, Częstochowa - North Subregion, and Rybnik - West Subregion. result of the implementation of this strategy, the EU Cohesion Policy 2014-2020 goals are aimed at reinforcing policy performance, and focus on results and maximising the impact of EU funding through thematic concentration promoting a strategic and integrated approach in general, and to deliver a more targeted support of the Structural Funds in practice.

The tool implementing the objective in the current programming period is Integrated Territorial Investments. It is an instrument which continues and develops the activities of the communities within the integrated approach conducted in the 1970s and 1980s (e.g. Integrated Development Operations and Integrated Mediterranean Programmes) (Pietrzyk 2004). In the current perspective, ITIs are a tool introducing the urban dimension to the Cohesion Policy (EC 2014) and constitutes a legal response of the European Commission to the necessity to strengthen the integrated approach to development programming combining policies, sectors, and funds recently postulated by member countries. ITIs are treated as the driving force of integration of activities for sustainable development of cities and their functional areas (FUAs). Moreover, the objective of ITIs is:

- an increase in the effect of FUAs on the shape and way of performance of activities supported in their area in the scope of the Cohesion Policy;

- strengthening mechanisms for territorial coordination of interventions through the implementation of integrated projects responding in a comprehensive way to the needs, challenges, and problems of functional urban areas;

- shaping the culture of partnership, promoting the partnership model of cooperation of LGUs in the governance of EU funds (CEC 2014).

In a broader context, ITIs aim at the introduction of thematic concentration in selected geographic areas, i.e. the concentration of regional policy interventions on strategic areas/potentials determining the competitiveness of regions/ territories in a longer term. This occurs through limiting interventions to particular categories of intersectoral activities / projects, responding comprehensively to the needs and problems of cities and their functional areas in the scope of selected strategic areas (CEC 2014). 


\section{Legal and organisational basis}

The legal basis for the ITI introduction at the EU level is determined by 3 regulations of the European Parliament and the EU Council of 17 December 2013, i.e. the General Regulation No. 1303/2013 (Article 36), the Regulation of European Regional Development Fund No. 1301/2013 (Article 7), and the Regulation of European Social Fund No. 1304/2013 (Article 12). The ITI is expected to support integrated actions at different territorial scales (cities, FUAs, regions, cross-border areas). ITIs can be financed within thematic objectives (TO) 1-10 for the European Structural and Investment Funds (ESIF) and have favourable rules of financing, including the combination of funding from the ERDF, ESF and Cohesion Fund (complemented with financial support from the EAFRD or the EMFF ) under more than one priority axis (PA) of one or more operational programmes (OP). Thus, a relevant operational programme or programmes will describe the approach to the use of the ITI and the indicative financial allocation from each priority axis (Article 36 of the General Regulation). Pursuant to the requirement of the European Commission, member states are obliged to allocate a minimum of $5 \%$ of the pool of resources from the ERDF to ITI implementation. Each country has to specify the rules of selection of areas for the implementation of integrated actions, and estimated an indicative allocation for those actions at the national level in its Partnership Agreement (PA) (Article 7 of the ERDF regulation).

The ex-ante condition of obtaining financing is particularly the establishment of an ITI union and the development of an ITI strategy. ITI unions develop institutionalised partnerships of ITI implementing entities. Pursuant to Article 7(4) of the ERDF Regulation, the ITI union shall be responsible for tasks relating, at least, to the selection of operations for the implementation. This permits "/.../ the managing authorities to delegate the implementation of parts of different priority axes to one body (a local authority) to ensure that investments are undertaken in a complementary manner" (CEC 2012, 9). It means that the member state or the managing authorities (MA) of an OP may designate one or more intermediate bodies (IBs) (local authorities, regional development bodies, NGOs) to carry out the management and implementation of an ITI (Article 36 of the General Regulation). The ITI strategy is an intersectoral territorial strategy mentioned in Article 7 of the ERDF regulation and Article 12 of the ESF regulation. Pursuant to Article 7 of the regulation of the ERDF, the strategy specifies integrated activities for the purpose of liquidation of demographic, social, environmental, and climatic problems occurring in urban areas. It should be based on development needs and result from territorial and demographic analyses. It has to be coherent with the development objectives of the country and region. ITI strategies aim at linking the thematic objectives specified in the Partnership Agreement (PA) or other territorial arrangements and provisions of regional/national operational programmes with the territorial dimension.

\section{ITI implementation in EU countries}

The territorial approach to the intraregional policy, i.e. addressing intervention packages to particular types of territories, and diversifying activities depending on the features of particular areas has become one of the tasks of regional policy, and the selection of areas aimed at concentrating interventions has become one of the challenges of EU countries. In practice, ITIs are implemented in 20 EU countries (12 use ITIs outside Article 7), whereas the mechanism of implementation in each of the countries is characterised by a variability of features, as well as a diverse thematic, geographic, financing and organisational approach (Biniek et al. 2016; van der Zwet, Bachtler 2018). The ITI instrument supports functional urban areas in countries such as Poland, the Czech Republic, or Slovakia. In Great Britain, Belgium, or Germany, it is only applied in selected regions (Cornwall and the Isles of Scilly; provinces Limburg, Kempen, West Flanders; BadenWurtemberg, Schleswig-Holstein). In Finland ITIs support the development of Helsinki, Espoo, Vantaa, Oulu, Tampere, Turku which implemented the 'Six City Strategy' (6Aika).

According to the financial data, the total allocated funding to ITIs is $€ 13.8$ billion, most of which ( $€ 11.8$ billion) is funded through the ERDF, with $12 \%$ ( $€ 1.7$ billion) funded through the ESF and 0.3 billion from Cohesion Fund. Nine member states decided to use resources combined 
from the ERDF and ESF in ITI implementation. Almost $80 \%$ of this ITI funding is concentrated in nine member states. The greatest financing of ITIs was obtained by Poland ( $€ 3.8$ billion).

Fifteen member states use the allocation of ITIs under the ERDF either entirely (e.g. Greece, Finland, Croatia, Latvia, Lithuania, Luxemburg, Netherlands, Poland, Slovenia, Slovakia, United Kingdom) or partly (Czech Republic, France, Italy, Sweden), which represents around half of the total allocated budget ( $€ 7.1$ billion) (van der Zwet, Bachtler 2018).

\section{ITI implementation in Poland - summary of current works}

\section{General rules of ITI implementation}

An ITI is aimed at the territorialisation of interventions and strengthening cooperation between LGUs in the implementation of the Cohesion Policy. Due to this, it is of key importance to designate areas of intervention and establish inter-municipal cooperation. The decision on the involvement of Poland in ITI implementation was taken in 2012. The Ministry of Regional Development (institution responsible for the implemented tool) passed a decision that ITIs will be implemented obligatorily in FUAs of voivodeship capitals (FUAs of VCs), and complementarily in FUAs of regional and subregional centres - depending on separate decisions of voivodeship authorities (Principles of accommodating..., January 2013). In the scope of preparatory works, several necessary activities were performed, resulting in: firstly, the delimitation of FUAs of voivodeship centres (Delimitation criteria..., February 2013) as a precondition for the establishment of LGU partnership, and development of the ITI strategy; secondly, preparation of ministry detailed guidelines describing the rules of ITI implementation in Poland (Principles for the implementation... July 2013); and thirdly, undertaking efforts for the purpose of preparation of a Partnership Agreement (PA) including the rules of ITI implementation and the act that would determine standards and regulate procedures of implementation of the Cohesion Policy, including ITI tools (they both came into force in 2014). The provisions of the Partnership Agreement
(2014) were transferred to the system of national legislature in the so-called implementation act ${ }^{3}$.

Table 1 presents the basic characteristics of the implementation of ITIs in the Polish Cohesion Policy in the 2014-2020 programming period.

In practice, ITIs are implemented in 26 FUAs in Poland. These include 17 FUAs of voivodeship centres (due to the contiguity of the functional areas of Bydgoszcz and Torun, a common ITI was established) and 9 implemented in the FUAs of regional centres (FUAs of RCs) or subregional centres (FUAs of SCs). Financing of ITIs occurs through projects implemented in the scope of 16 ROPs and national operational programmes: Infrastructure and Environment 20142020, Eastern Poland 2014-2020 (5 voivodeships of Eastern Poland: Lubelskie, Podkarpackie, Podlaskie, Świętokrzyskie, and WarmińskoMazurskie), to a low degree in the scope of the Operational Programme Technical Assistance 2014-2020. ITIs are implemented through designated measures or submeasures in the scope of at least two priority axes of the regional operational programme financed from two structural funds (Article 30, point 3 of the Implementation Act). In the case of Poland, they are the ERDF and ESF. Projects implemented in the scope of an ITI focus around eight directions of intervention, and combine eight thematic objectives. The highest number of directions is combined in TO8 (Table 2) (PA 2014).

Pursuant to the provisions of Principles of accommodating... (2013: 11), at least $5 \%$ of structural funds (EFRR, EFS) from the so-called programming reserve were aimed to be allocated for the implementation of ITIs in FUAs of voivodeship centres, and the division of resources between 16 ROPs was to be based on an algorithm particularly considering criteria specifying the number of residents of the functional urban area. Pursuant to the detailed provisions of the Partnership Agreement (2014), a total of $€ 2.4$ billion was obligatorily reserved for the basic allocation of voivodeship ITIs in 16 ROPs $^{4}$, whereas

Act of 11 July 2014 on the principles of implementation of the cohesion policy programmes, financed under the 2014-2020 financial perspective (Journal of Laws 2014, item 1146 as amended).

4 At the level of all ROPs, the total allocation for the implementation of ITIs in FUAs of VCs in comparison to the total allocation of particular funds for Poland 
Table 1. Characteristics of the implementation of ITIs in Poland.

\begin{tabular}{|l|l|}
\hline \multicolumn{1}{|c|}{ Characteristic } & \multicolumn{1}{c|}{ ITI } \\
\hline objective & $\begin{array}{l}\text { strengthening mechanisms for territorial coordination of interventions responding to the func- } \\
\text { tional urban areas' (FUAs) needs and problems, as well as promoting administrative units' } \\
\text { cooperation in the management of EU funds and territorial development of FUAs; }\end{array}$ \\
\hline measures & $\begin{array}{l}\text { promoting the partnership model of cooperation between the different administrative units in } \\
\text { functional urban areas in the management of EU funds; } \\
\text { implementation of cross-sectoral territorial strategies through linking thematic objectives spec- } \\
\text { ified in the Partnership Agreement (PA 2014) and regional operational programmes (ROP) to } \\
\text { the territorial approach; } \\
\text { implementation of joint cross-sectoral, integrated projects responding comprehensively to the } \\
\text { needs and problems of cities and their functional areas; }\end{array}$ \\
\hline financing measures & $\begin{array}{l}\text { ESIF TO1-10; } \\
\text { combining funding of one project (implemented in the form of bundles of projects) from dif- } \\
\text { ferent funds (ERDF, ESF) from several priority axes and operational programs; }\end{array}$ \\
\hline implementation & $\begin{array}{l}\text { under 16 ROPs; } \\
\text { under selected NOPs (OP Infrastructure and Environment and OP Eastern Poland); }\end{array}$ \\
\hline ex-ante conditions & $\begin{array}{l}\text { appointing the ITI union by establishing an institutionalised form of partnership (arrange- } \\
\text { ment, association, or inter-municipal union); } \\
\text { developing ITI strategy identifying problems, determining the directions of intervention and } \\
\text { including the list of projects; } \\
\text { concluding an agreement for the implementation of ITI between the ITI union and the manag- } \\
\text { ing authority (MA) of ROP; }\end{array}$ \\
\hline area of intervention & $\begin{array}{l}\text { obligatory in 17 FUAs of voivodeship centres (FUA VC); } \\
\text { optionally in 9 selected FUAs of regional centres (FUA RC) and FUAs of subregional centres } \\
\text { (FUA SC). }\end{array}$ \\
\hline
\end{tabular}

Source: own study based on Principles for the implementation... (2013), Partnership Agreement (2014).

Table 2. Combining the directions of intervention with thematic objectives.

\begin{tabular}{|c|c|}
\hline Direction of intervention & Thematic objective \\
\hline dynamisation of efficient and sustainable transport connecting the city and its functional area & TO4, TO7 \\
\hline $\begin{array}{l}\text { restoration of socio-economic functions in degraded areas included in the composition of the } \\
\text { functional urban area }\end{array}$ & $\begin{array}{l}\text { TO6, TO8, TO9, } \\
\text { TO10 }\end{array}$ \\
\hline improvement of the state of the natural environment of the city and its functional area & TO4, TO6 \\
\hline strengthening of energy efficiency, and popularising low-emission strategies & TO4 \\
\hline $\begin{array}{l}\text { strengthening of symbolic functions building the international character and supraregional } \\
\text { rank of a given functional area of the city }\end{array}$ & TO1, TO3 \\
\hline improvement of the situation on the labour market & TO8, TO10 \\
\hline improvement in accessibility of public services & TO8, TO9, TO10 \\
\hline services concerning health protection, prophylaxis, and social services & TO8, TO9 \\
\hline
\end{tabular}

Source: own study based on the Partnership Agreement (2014).

"the amount should be increased by the amount considered necessary by the regional authorities" (PA 2014: 228). The highest allocation in the scope of voivodeship ITIs was planned in Śląskie Voivodeship with the Central Subregion with approximately 2.7 million inhabitants $-20 \%$ of the total resources, followed by Małopolskie (9\%), Pomorskie (8\%), and Łódzkie Voivodeships (7\%). The lowest support was planned to be granted to Warmińsko-Mazurskie Voivodeship (approximately $2 \%$ of voivodeship allocations).

is at least $5.2 \%$ of allocation of the ERDF and $2.4 \%$ of allocation of the ESF (PA 2014: 228).
Considerably smaller financing for the Warszawa FUA (2.7 million residents) results from its location in Mazowieckie Voivodeship - a region in the transitional phase. Resources for five weakly populated voivodeships of Eastern Poland were planned to constitute a total of $15 \%$ of the amount allocated to ITIs (Fig. 1).

Conditions of ITI implementation include: 1) the establishment of an ITI union; 2) the preparation of an ITI strategy and a positive opinion on it given by: a) the managing authority of a regional operational programme (MA ROP) within the possibilities of ITI financing under this programme, b) the minister in charge of regional 


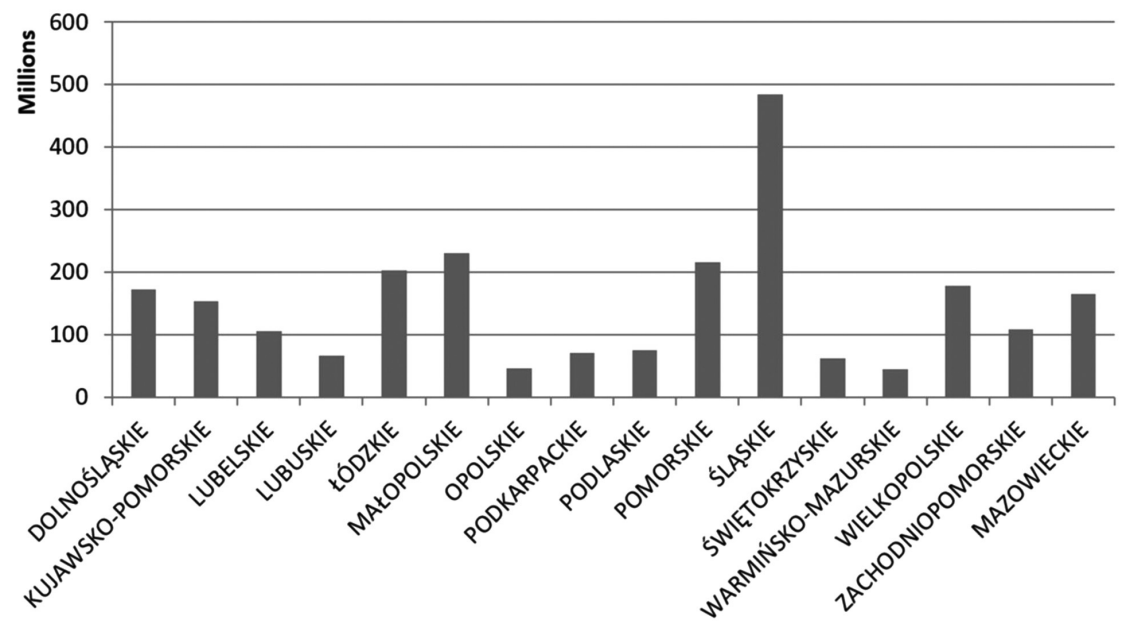

Fig. 1. Basic allocation in 16 ROPs for 'voivodeship' ITIs (in million EUR). Source: own study based on Partnership Agreement (2014).

development in accordance with the partnership agreement and the possibilities of financing projects from national operational programmes, if stipulated by the ITI strategy; 3) concluding an arrangement or agreement concerning ITI implementation between an ITI union and the relevant governing institution of ROP, particularly including the scope of entrusted tasks, covering at least the participation of the ITI union in the selection of projects for financing by the relevant governing institution of ROP and cooperation with MA in the preparation of criteria of selection of projects for designated measures or submeasures for ITI implementation (Article 30, point 5 of the Implementation Act). The implemented projects are selected in 2 modes: a) open call for proposals - the projects are chosen by the ITI union based on the rules arranged with MA ROP and included in the ITI strategy; b) restricted call for proposals - it is obligatory to enter projects in the ITI strategy in the form of a list of strategic projects. Moreover, in order to emphasise the complementary character of the project, its relations with other projects should be presented.

The ITI union can take form of an arrangement of self-governments, an association, or intercommune union (Principles for the implementation... 2013; PA 2014). The ITI strategy specifies in particular: 1) the diagnosis of the area of implementation of an ITI together with the analysis of developmental problems; 2) objectives to be implemented in the scope of an ITI, expected results and result and product indicators related to the implementation of the regional operational programme; 3) proposals of project selection criteria in the course of an open call for proposals; 4) a preliminary list of projects selected in the restricted call for proposals together with information on the way of their designation and linking to other projects, including those selected in the restricted call for proposals subject to positive opinions by the governing institution of the national operational programme; 5) sources of its financing; 6) conditions and procedures binding in the implementation of the ITI strategy (Article 30, point 8 of the Implementation Act). The legal basis of the ITI strategy is provided by the decision of the management board of an ITI union. The strategy and its amendments are prepared in cooperation with the relevant MA ROP and passed by the ITI union in the form of a resolution. The ITI strategy designates areas included in the composition of FUAs in which support is to be implemented (Principles for the implementation... 2013). Therefore, the most important issue at the first stage of ITI implementation was the delimitation of the support area, i.e. the determination of FUA boundaries.

\section{Delimitation}

Considering that functional urban areas appeared in planning-strategic documents in 2011 (National Spatial Development Concept 2011) and no guidelines were provided as to how to perform their delimitation, the Ministry of Regional Development commissioned the preparation of a document that would specify the 


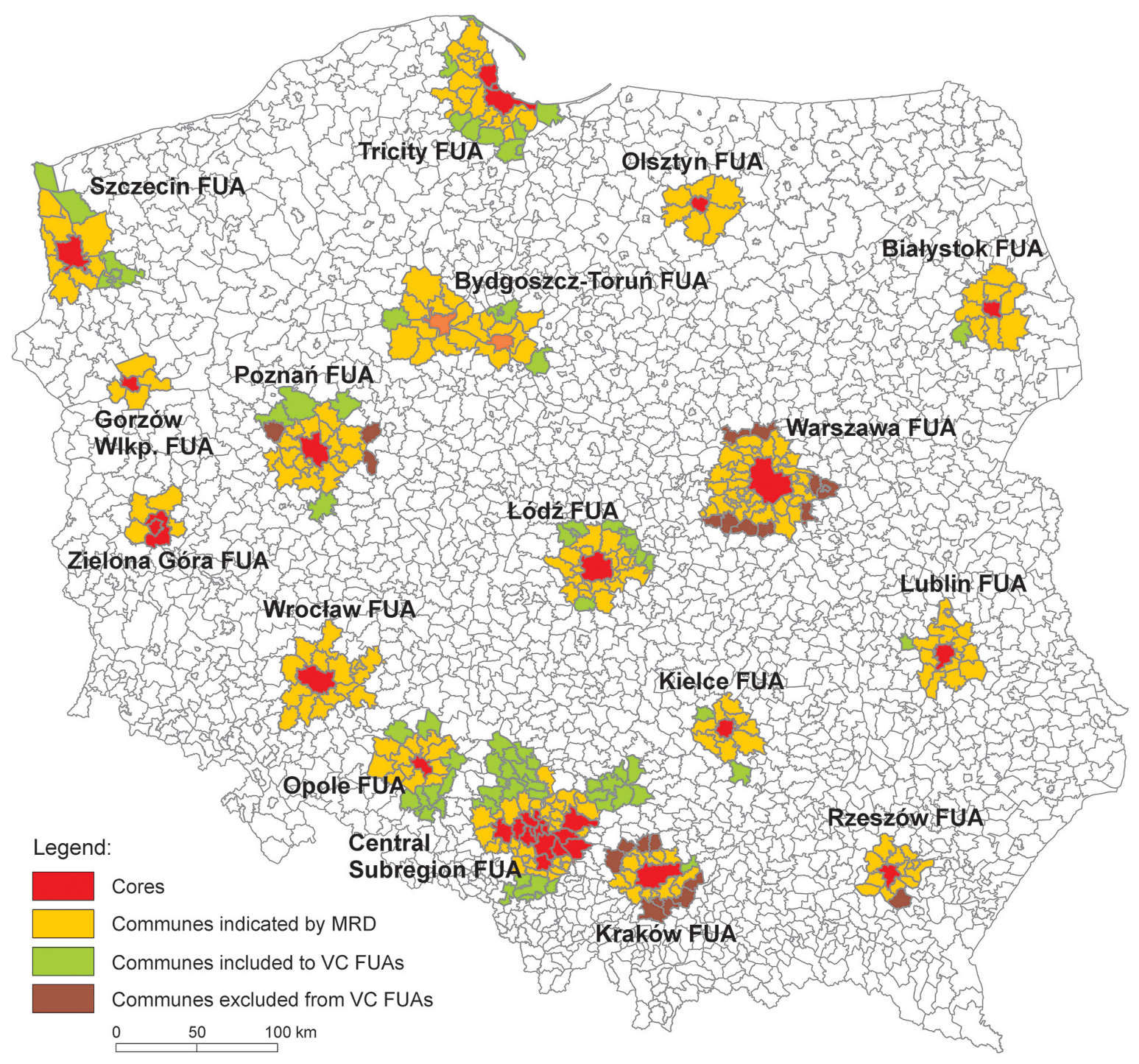

Fig. 2. Spatial range of the proposed FUAs of VCs and ITI support areas in practice. Source: own study based on D. Kociuba 2017a.

areas of implementation of voivodeship ITIs. The document published in February 2013 entitled Delimitation criteria of functional urban areas of voivodeship centres, based on 7 statistical indices, specified ITI support areas for 18 voivodeship capitals (VC) (in the case of FUA of Bydgoszcz and Torun - the capitals of Kujawsko-Pomorskie located relatively near each other, a single support area was designated) (Śleszyński 2013). Practice showed (Fig. 2) that ministerial delimitation was adopted in only 4 FUAs of voivodeship capitals (Wrocław, Zielona Góra, Gorzów Wielkopolski, Olsztyn). The remaining ones increased or reduced the ITI support area. This resulted, on the one hand, from earlier cooperation (Poznan, Szczecin, Tricity), arrangements of strategic documents at the regional level (Katowice, Łódź), arrangements of expert documents (BydgoszczToruń, Kielce), decisions of ITI unions (Warszawa, Kraków, Opole), or compromise between what the ministry proposed and what communes eventually declared cooperation in ITI implementation (remaining ones). They correspond with variants of delimitation in the following order: ministry, cooperation, strategic-planning, expert, and interim) (Kociuba 2017a).

The implementation of regional and subregional ITIs was undertaken by the authorities of 5 voivodeships:

1. Dolnośląskie, where two near-border FUAs were designated, namely for Wałbrzych and Jelenia Góra, 
Table 3. Area, population and number of communes implementing ITIs in Poland.

\begin{tabular}{|l|c|c|c|}
\hline & FUAs of voivodeship centres & FUAs of regional and subregional centres & Total \\
\hline area (in thou. $\mathrm{km}^{2}$ ) & 38.5 & 16.5 & 55.0 \\
\hline population (in million) & 14.8 & 3.3 & 18.1 \\
\hline number of communes & 348 & 181 & 529 \\
\hline
\end{tabular}

Source: own study.

2. Wielkopolskie - Kalisz-Ostrów FUA,

3. Warmińsko-Mazurskie - FUAs of Elbląg and Ełk,

4. Zachodniopomorskie - coastal FUA of Koszalin-Kołobrzeg-Białogard,

5. Śląskie - FUA of Bielsko-Biała - South Subregion, Częstochowa - North Subregion and Rybnik - West Subregion (their delimitation resulted from the division of Śląskie Voivodeship in the Silesian Strategy 2020+).

Eventually, ITIs are implemented in $21.3 \%$ of communes in Poland, occupying a total of $17.5 \%$ of the area, and inhabited by $47.6 \%$ of the population of the country (Table 3 ).

\section{Intercommune cooperation as the basis for the establishment of ITI unions}

Tracing the cooperation of LGUs in some cases resulting in the establishment of ITI unions shows certain patterns. The first forms of cooperation of LGUs in metropolitan areas of cities were recorded in the years 2000-2002 and 2005-2008, and particularly represented informal forms of cooperation, i.e. councils, partnership arrangements, development agencies, and more seldom took forms of institutionalised cooperation, i.e. as an association. The next period 2010-2011 brought the registration of municipal unions (Gorzów Wielkopolski, West Subregion) and associations led by Bydgoszcz, Poznań, Szczecin, Częstochowa, and neighbouring cities of Gdańsk and Gdynia. Cases of long-lasting cooperation of neighbouring communes also occurred with the exclusion of a central city (Warszawa, Rzeszów). A large majority of cooperation was established in the years 2013-2014. This was directly related to the possibility of use of investment financing under the ITI instrument (Table 4).

It should be emphasised that only few previously formalised partnerships got involved in ITI implementation adopting the role of the ITI union. This happened in the case of the FUAs of Poznan, Szczecin, Tricity, and the West Subregion. The role of the ITI union was not taken over by institutions with the longest history of inter-self-government

Table 4. Legal and organisational forms of cooperation of LGUs and institutionalisation of ITI unions in selected FUAs in Poland.

\begin{tabular}{|c|c|c|c|c|}
\hline Name of FUA & Form of partnership & $\begin{array}{l}\text { Establishment } \\
\text { of partnership }\end{array}$ & $\begin{array}{l}\text { Entrusting the role } \\
\text { of IB to ITI union }\end{array}$ & $\begin{array}{c}\text { Scope of task } \\
\text { delegation }\end{array}$ \\
\hline \multicolumn{5}{|c|}{ FUA VC } \\
\hline \multirow[t]{2}{*}{ Białystok FUA } & arrangement & 2005 & & \\
\hline & association & 2013 & 2014 & 1 \\
\hline \multirow[t]{4}{*}{ Bydgoszcz-Toruń FUA } & arrangement & $2005 / 2008$ & & \\
\hline & association & 2010 & & \\
\hline & arrangement & 2014 & $2014 / 2016$ & 2 \\
\hline & association & 2015 & & \\
\hline \multirow[t]{6}{*}{ Gdańsk-Gdynia-Sopot (Tricity) FUA } & council & 2003 & & \\
\hline & association & 2006 & & \\
\hline & arrangement & $2011 / 2012$ & & \\
\hline & association & 2011 & & \\
\hline & arrangement & 2014 & 2014 & \\
\hline & association & 2015 & 2015 & 2 \\
\hline \multirow[t]{3}{*}{ Gorzów Wielkopolski FUA } & association & 1999 & & \\
\hline & arrangement & 2011 & & \\
\hline & arrangement & 2013 & 2015 & 2 \\
\hline \multirow[t]{2}{*}{ Central Subregion (Katowice) FUA } & association & 2007 & & \\
\hline & association & 2013 & 2013 & 2 \\
\hline
\end{tabular}


Table 4 contiuned.

\begin{tabular}{|c|c|c|c|c|}
\hline Name of FUA & Form of partnership & $\begin{array}{l}\text { Establishment } \\
\text { of partnership }\end{array}$ & $\begin{array}{l}\text { Entrusting the role } \\
\text { of IB to ITI union }\end{array}$ & $\begin{array}{c}\text { Scope of task } \\
\text { delegation }\end{array}$ \\
\hline Kielce FUA & arrangement & 2013 & 2013 & 2 \\
\hline \multirow[t]{2}{*}{ Kraków FUA } & council & 2007 & & \\
\hline & association & 2013 & 2014 & 2 \\
\hline \multirow[t]{3}{*}{ Lublin FUA } & arrangement & 2005 & & \\
\hline & agreement & 2014 & & \\
\hline & arrangement & 2015 & 2015 & 2 \\
\hline Łódź FUA & association & $2012 / 2013$ & 2015 & 2 \\
\hline \multirow{2}{*}{ Olsztyn FUA } & association & 2013 & & \\
\hline & arrangement & 2013 & 2014 & 2 \\
\hline \multirow[t]{2}{*}{ Opole FUA } & arrangement & 2012 & 2013 & \\
\hline & association & 2013 & 2014 & 3 \\
\hline \multirow{2}{*}{ Poznań FUA } & council & 2007 & & \\
\hline & association & 2011 & 2013 & 2 \\
\hline \multirow[t]{4}{*}{ Rzeszów FUA } & arrangement & 2005 & & \\
\hline & association & 2008 & & \\
\hline & arrangement & 2014 & & \\
\hline & association & 2015 & 2015 & 2 \\
\hline Szczecin FUA & association & $2005 / 2009$ & 2015 & 1 \\
\hline \multirow[t]{2}{*}{ Warszawa FUA } & association & 2000 & & \\
\hline & arrangement & 2014 & 2014 & 2 \\
\hline \multirow[t]{3}{*}{ Wrocław FUA } & development agency & 2006 & & \\
\hline & association & 2013 & & \\
\hline & arrangement & 2013 & 2015 & 2 \\
\hline \multirow[t]{3}{*}{ Zielona Góra FUA } & association & 2006 & & \\
\hline & association & 2011 & & \\
\hline & arrangement & 2014 & 2014 & 2 \\
\hline \multicolumn{5}{|c|}{ FUA RC/SC } \\
\hline \multirow[t]{2}{*}{ Wałbrzych FUA } & cooperation declaration & 2013 & & \\
\hline & arrangement & 2015 & 2015 & 3 \\
\hline \multirow[t]{2}{*}{ Jelenia Góra FUA } & cooperation declaration & 2012 & & \\
\hline & arrangement & 2015 & 2015 & 2 \\
\hline \multirow[t]{2}{*}{ Kalisz-Ostrów FUA } & arrangement & 2008 & & \\
\hline & association & 2015 & 2015 & 2 \\
\hline Koszalin-Kołobrzeg-Białogard FUA & arrangement & 2014 & 2015 & 2 \\
\hline Ełk FUA & arrangement & 2014 & 2015 & 2 \\
\hline \multirow[t]{3}{*}{ Elbląg FUA } & arrangement & 2013 & & \\
\hline & agreement & 2014 & & \\
\hline & arrangement & 2014 & 2016 & 2 \\
\hline South Subregion (Bielsko-Biała) FUA & arrangement & 2015 & 2016 & 2 \\
\hline \multirow[t]{2}{*}{ North Subregion (Częstochowa) FUA } & association & $1992 / 2000$ & & \\
\hline & arrangement & 2015 & 2015 & 2 \\
\hline West Subregion (Rybnik) FUA & union & 2002 & 2015 & 2 \\
\hline
\end{tabular}

1) designations of strategic projects,

2) recruitment, selection, and assessment of projects,

3 ) performance of the full procedure of call for proposals for the managing authority.

Source: own study based on Kociuba (2017) and selected ITI/RTI strategies of RC and SC FUAs.

cooperation, i.e. the Club of Heads of Communes, Mayors, and City Presidents of Częstochowskie Voivodeship established in 1992, or the SpecialPurpose Association of Communes MG6 functioning in the FUA of Gorzów Wielkopolski since
1999. An interesting example is the Tricity FUA, where an arrangement was first concluded, and then the role of the ITI union was overtaken by the newly established Association Gdańsk-GdyniaSopot Metropolitan Area, stemming from the 
compromise between the activity of competing associations, the Association of Self-Governments of the Gdańsk Metropolitan Area (with Gdańsk as the leader), and the (Metropolitan) Forum of Heads of Communes, Mayors, City Presidents, and Starostas 'NORDA' (with Gdynia as a leader). Although the majority of partnerships were established only for the purpose of ITI implementation $^{5}$, the formalisation of the cooperation and the resulting further activities offer actual possibilities for the enactment of territorial governance in FUAs.

\section{Legal form of the ITI union}

In the implementation of the rules of territorial governance - one of the objectives of ITI implementation - a very important issue is the degree of formalisation of partnerships that can influence the quality and rate of strategic programming of development and governance of FUAs (Kociuba 2017). In the functioning of an ITI union, the cooperation of cities/communes in programming the development and governance of FUAs (above the administrative boundaries of a particular LGU) seems to be the most important. In practice, the cooperation took a more or less institutionalised form (Table 3). In 9 out of 17 FUAs of VCs (those of Białystok, Tricity, Central Subregion, Kraków, Łódź, Opole, Poznań, Rzeszów, and Szczecin) and 1 FUA RC (Kalisz-Ostrów Agglomeration Association), ITIs are implemented by associations fulfilling the function of ITI unions (Table 3). Such ITI unions have more formalised structures, including councils/general meetings with a decision making function, composed of representatives of all communes included in the association, management boards composed of several persons (selected representatives of LGUs from the functional area) - executory bodies and revision commissions - control bodies. ITI offices fulfil auxiliary functions. They provide administrative support. They can also prepare drafts of strategies. The intermediate body (IB ITI) in ITI implementation in the scope of ROPs is the management board of the association. The only so

They belong to ITI unions functioning in the functional areas of Białystok, Kielce, Lublin, Łódź, Central Subregion, Opole, Rzeszów, Warszawa, and all unions functioning in the FUA of RC/SC (except for the FUA of the West Subregion). far communal association, namely the Union of Communes and Poviats of the West Subregion of Śląskie Voivodeship, functions based on similar rules. In this case, the governance of the FUA is formalised and subject to full control.

The remaining 8 partnerships in FUA VC and 7 in RC FUAs and SC FUAs chose a less institutionalised form of cooperation, namely signing an arrangement on cooperation between the LGU for the purpose of common implementation of the ITI instrument (Table 3). In such a situation, the ITI union entrusts one of the units of territorial self-government, usually a voivodeship city, with tasks of the remaining entities, and is represented by the leader, usually the city president. The leader has the highest competences and the widest scope of the delegation of tasks. The role of the management board of the union is fulfilled by the council of the ITI union that can also be composed of socio-economic partners. Steering committees play an opinion-forming role, e.g. in the scope of acceptance of ITI strategies, and administrative functions are fulfilled by ITI offices usually within the structure of municipal offices. The remaining LGUs usually have their representatives in the council and steering committees. Adopting of the model by the majority of ITI unions proves the weakness of the culture of LGU cooperation. Unions in this legal form were established primarily for the purpose of consuming funds from ITI allocation, and their members had no earlier experience in intercommune cooperation (more in Kociuba 2017, 2017a; Kaczmarek, Kociuba 2017). Therefore, the safest solution for communes from the functional area proved to be transfer of the responsibility for the entire works involved in ITI implementation to the leader, which as a consequence further improves the strong position of the central city in a FUA.

\section{Delegation of tasks of the ITI union}

As already emphasised an ITI union (including local/municipal authorities) must fulfill the role of intermediate body (IB) and implement tasks related at least to the selection of projects for subsidies. In practice, the authorities of the ITI union submit to the MA of the ROP lists of projects selected for support, prioritised based on criteria approved by the monitoring committee of a ROP, concerning the degree in accordance 
with the objectives of the ITI strategy. The MA of ROP performs the final verification of the qualified character of projects for subsidies (unless the arrangement between the ITI union and MA of ROP stipulates otherwise). The organisation of recruitment and complete assessment of projects in formal and substantive terms can be performed by local authorities, including municipal or MA of ROP. The greater scope of delegated tasks, the greater the effect of the ITI union on the performance of activities and works related to the entire recruitment process, selection of contractors, allocation costs, and monitoring of projects.

In practice, the scope of competences of the ITI union as IB took three forms (Kociuba 2017) beginning with: 1) the identification of strategic projects (two ITI unions currently function in this form - Szczecin and Białystok), through 2) conducting recruitment, selection of projects in the ITI union/assessment of projects (22 ITI unions), 3 ) the performance of a complete procedure of an open call for proposals for the MA (Opole and Wałbrzych) (Table 3). From the perspective of building governance competences, taking full responsibility, also in the financial dimension, for ITI implementation seems to be of key importance. It is disturbing that experience in the scope is gained by only two ITI unions.

\section{Approval of ITI strategies}

The analysis of works on the development of the ITI strategies undertaken by ITI unions shows certain patterns. They are related to the delay of works on the implementation of the instrument, and particularly with delayed determination of the demarcation line between funds and activities financed in the scope of ROPs and NOPs. This led to a situation in which the strategies had to be edited among others by removing projects the financial feasibility of which was shifted to the national level. This caused delays in the approval of strategies in relation to the term of acceptance of $\mathrm{ROP}^{6}$ by EC and management boards of voivodeships. The delays were variable. In the case of the FUAs of Łódź, Warszawa, Kraków, and Ełk, the ITI strategy was accepted several months after the ROP approval. In the

$6 \quad$ The majority of ROPs were approved by the European Commission at the turn of 2104 and 2015. case of the remaining FUA, the acceptance of the strategy occurred after around a year, and in the FUAs of Bydgoszcz and Torun, Elbląg, the West Subregion, and Zielona Góra, after almost two years from the approval of ROPs.

\section{Financing of ITIs}

Poland is a beneficiary of the greatest amount of resources in the scope of ITIs. ITI implementation occurs owing to combining resources from two funds: the ERDF and ESF, whereas in the case of Poland they are particularly funds dedicated to ITIs pursuant to Article 7 of the general regulation, in the scope of the ERDF (€3.2 million), and to a much lower degree from the ESF (only $€ 0.5$ million). No financing in the scope of Cohesion Funds was stipulated. Approximately $€ 6.2$ billion is allocated for the implementation of integrated measures in Poland. In that pool, €3.8 billion are resources from 16 ROPs constituting the basic source of financing of ITIs.

Moreover, the projects are supported by own resources and from three national operational programmes: Infrastructure and Environment (OP IE), Eastern Poland (OP EP) (5 voivodeships: Lubelskie, Podkarpackie, Podlaskie, Świętokrzyskie, and Warmińsko-Mazurskie), to a low degree ( $€ 20$ million) in the scope of OP Technical Assistance (OP TA) (Fig. 3). Under 16 regional operational programmes (ROPs), the amounts allocated for ITIs in the scope of the ERDF is higher than the threshold determined by EC $(5 \%)$, and constitutes $8 \%$. Own resources are an additional support.

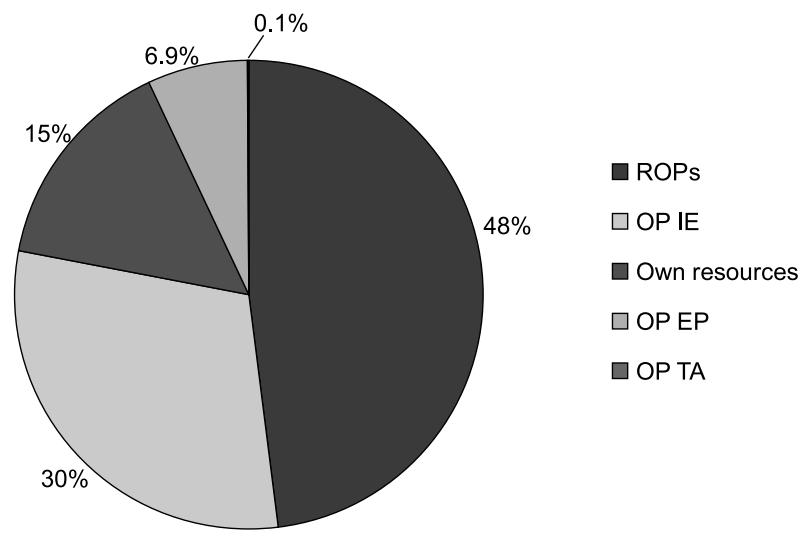

Fig. 3. Sources of financing of voivodeship ITIs with complementary sources.

Source: own study based on: https://www.funduszeeuropejskie.gov.pl. 


\section{Results of ITI implementation in Poland (state as at the end of May 2018)}

\section{Allocation for ITIs in ROPs and the level of contracting of dedicated ITI allocation in particular FUAs}

Support obtained by particular FUAs for ITI implementation differs from the provisions of Partnership Agreement (2014) (Fig. 2). In practice, allocation for FUAs of voivodeship centres in 16 ROPs reaches almost $€ 3$ billion, whereas the lowest support among voivodeship ITIs was obtained by weakly populated FUAs of VCs in Lubuskie Voivodeship: Gorzów Wlkp., Zielona Góra (at a level of $€ 50-58$ million), and the highest, except for the Central Subregion comprising 71 communes inhabited by a total of 2.7 million residents (more than $€ 760$ million), Gdańsk-Gdynia-Sopot
(Tricity) (€247 million), and Kraków (€236 million), also Wrocław (€264 million) and Łódź (more than $€ 225$ million). For the FUAs of Lublin, Białystok, and Warszawa, allocation changed only inconsiderably in comparison to the assumptions of the Partnership Agreement. ITIs in FUAs of regional and subregional centres are financed in the scope of the basic allocation in 5 ROPs to the total amount of $€ 760$ million. Attention should be paid to the high financing of ITIs in the FUAs of Wałbrzych and Jelenia Góra, and subregions in Śląskie Voivodeship, with amounts approximate to the allocation for ITIs for Lublin and Szczecin, and in the case of Wałbrzych exceeding allocation for ITIs in the Warszawa FUA (in the group of transition regions). The remaining ITI unions negotiated relatively low amounts in this aspect, particularly those in Warmińsko-Mazurskie Voivodeship (the FUAs of Olsztyn, Elbląg and Ełk, €97 million in total) (Fig. 4).

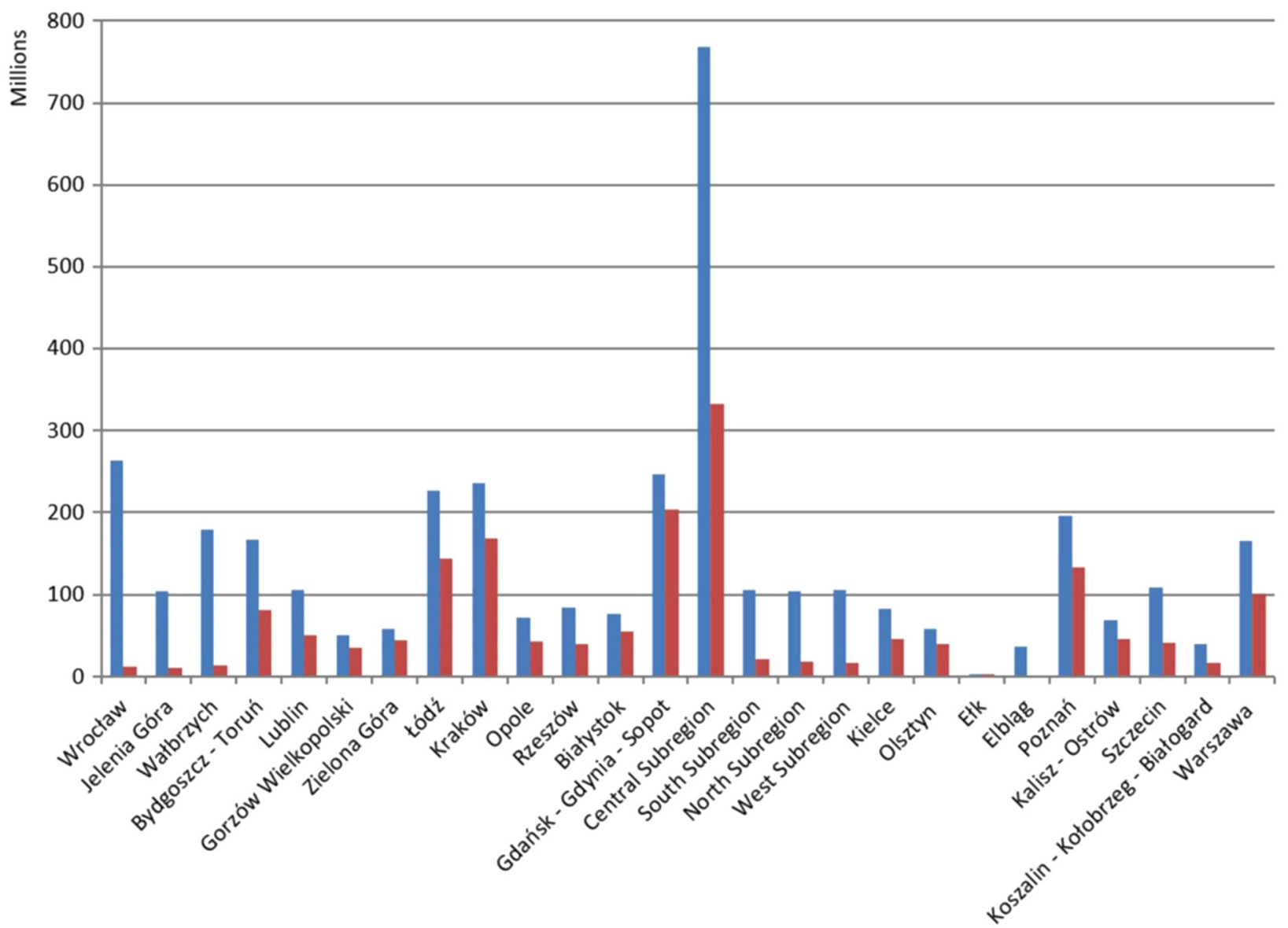

Fig. 4. Allocation for ITIs under ROPs (blue colour) and resources contracted by the end of May 2018 (red colour) (in million EUR), state as of May 2018.

Source: own study based on 16 ROPs and 16 detailed description of priority axes of regional operational programmes, and the website of the Ministry of Investment and Economic Development (https:// www.funduszeeuropejskie.gov.pl). 


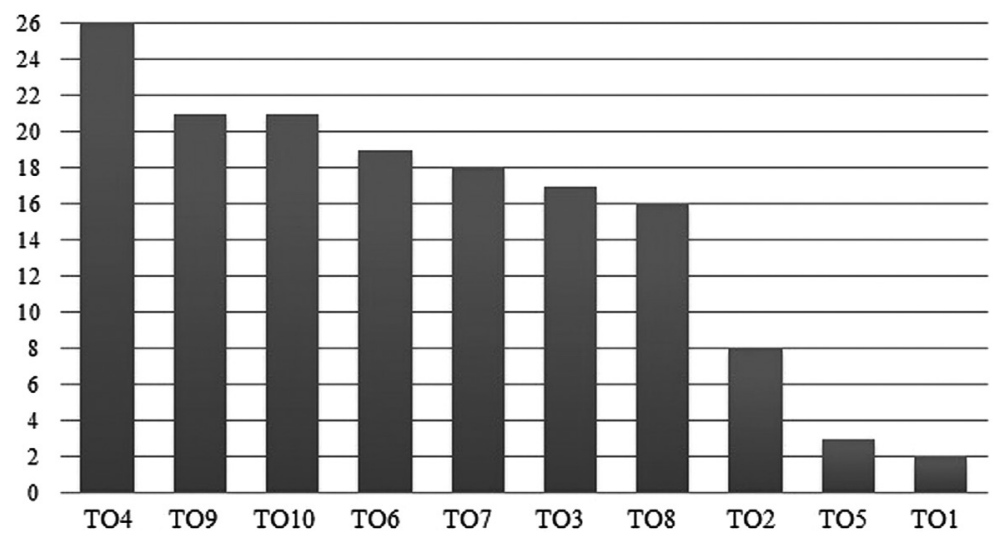

Fig. 5. Frequency of investment indications under thematic objectives in 26 ITI strategies. Source: own study.

Until the end of May 2018, more than 1500 projects were contracted under 16 ROPs to a total amount of more than $€ 1.7$ billion. The analysis of contracting of ITIs shows high advancement of works in the Gdańsk-Gdynia-Sopot FUA (where the implementation of more than $80 \%$ of projects has been contracted), as well as Zielona Góra, Kraków, Gorzów Wielkopolski, and Białystok (more than $70 \%$ ). Activities related to the implementation of projects in the scope of ITIs in the FUA of Wrocław are very slow - only 3.5\% of the allocation has been used, and in regional and subregional FUAs (approximately 10\% on average, and in Elblacg no project has been contracted yet) (Fig. 4). It is noticeable that the difficulties in contracting occur especially where the diversity and dispersion of undertaken measures is the greatest (Dolnośląskie and Śląskie Voivodeship), and the lowest - in subregional centres which not only obtained the lowest financial support for the implementation of ITIs, but also have no experience in earlier cooperation of LGUs (Kociuba, Szafranek 2018).

\section{Directions of intervention, thematic and substantive scope of projects}

ITI unions had a choice of eight directions of intervention, combining eight thematic objectives. In practice, they decided to use to the greatest extent: financing in the scope of $\mathrm{TO} 4$ supporting the shift towards a low-carbon economy in all sectors (all 26 ITI strategies stipulate financing in the scope of this TO), TO9 promoting social inclusion, combating poverty and any discrimination, and TO10 aimed at investing in education, training, and vocational training for skills and lifelong learning (21 ITI unions each). Although PA does not stipulate the implementation of undertakings under the implementation of $\mathrm{TO} 2$ and TO5, part of the ITI unions decided to take this step and negotiated their financing under ROPs (Fig. 6).

The most popular measures are directed at the development of public transport and construction of cycling paths (implemented by all ITI unions under investment priority $4 \mathrm{e}$ ), the development of educational programmes for pupils (under IP 10i), implemented in $20 \mathrm{FUAs}$, and financing of thermomodernisation of public purpose buildings (IP 4c). Financing of activities directed at the development of R\&D infrastructure and an increase in innovations in enterprises, as well as improvement in the accessibility of social services was only undertaken by single ITI unions (Fig. 7).

\section{What do ITIs support?}

ITIs are assumed to support territorialisation of investments in functional urban areas, and directions of interventions, like the entire Cohesion Policy implementing the provisions of the Europe 2020 Strategy, should strengthen the competitive position of FUAs in three dimensions: smart, sustainable, and inclusive.

The presented review shows that the lowest popularity among ITI unions shaping sustainable development of FUAs concerned activities supporting building "smart" economy and society (in the scope of TO1, TO2, and TO3), whereas the need to support enterprises and the development of R\&D infrastructure was recognised to the lowest degree. This was related to a change 
in the demarcation line in the implementation of TO1. Resources are the most frequently allocated for connecting utilities to the building land (17 FUAs), providing possibilities of attracting investors. Only 8 ITI unions took the decision on financing the implementation of e-services in public administration. This does not result from the fact that the condition of Polish administration in this scope is sufficiently good and does not require new investments (Gonciarski, Mazurek 2014; Śledziewska, Zięba 2016), but from the priority character of other measures.

In the context of implementation of the 'sustainable' component, the priority was the development of public transport together with the purchase of new low-emission fleet, or the expansion of cycling paths (all the analysed FUAs, but only 3 will invest in the modernisation and construction of public transport infrastructure) and construction and modernisation of roads (16 FUAs). Activities related to thermomodernisation also have been enjoying popularity for many years (19 FUAs). In this context, it is disturbing that activities related to support using renewable energy sources will be conducted only in 5 FUAs. It is also disturbing that, in the conditions of the vast disproportion in the provision of water supply and the sewage network, ITI unions mostly supported the expansion of the water supply network (11 FUAs), and to a much lower extent (only 4 FUAs) the expansion of the sewage network that is evidently lacking, especially in suburban communes under strong urbanisation pressure (Kociuba, Matacz 2018).

In the aspect of strengthening the 'inclusive' component, ITI unions prioritise the development of educational programmes for pupils and students, particularly in technical and IT courses (20 FUAs), training for pupils/students and the improvement of teachers' competences in vocational schools (16 FUAs). This is in strong relation to the crisis of vocational and technical education in Poland (System szkolnictwa ... 2016; Chłon-Domińczak et al. 2016; EC 2016). It is characteristic that new equipment and facilities in such schools, usually obsolete ${ }^{7}$, are subject to

Schools in Poland are financed from the budget of communes and cities, hardly sufficient for payment of salaries for teachers. The majority of schools experience a chronic deficit of resources. Due to this, a multimedia projector, laptop, interactive board or good investment in only 3 FUAs (!). This results from that fact that it is easier to develop an education or training programme, and it is much more difficult to conduct a tender. Due to this, relatively many ITI unions (16) took the decision on financing the development of support and training programmes for persons threatened with social exclusion (16 FUAs) and the unemployed (12 FUAs), as well as on implementing a number of 'soft' measures for local communities (16 FUAs), which perfectly corresponds with the implementation of the assumptions of the 'inclusive' pillar, but raises doubts that the resources will be 'eaten' in catering with no substantial results for the development of the entire FUA. It should be emphasised that only 10 FUAs used the possibility to build and equip kindergartens and nurseries which are in deficit throughout the country (EC 2016; The System... 2018) $)^{8}$, and the current policy of the government, at least based on its assumptions, favours the improvement in fertility. The approach to the problem of aging of society looks much better in these terms - 15 ITI unions have planned to finance investments in health infrastructure, particularly those for the elderly. Financial support for persons commencing business activity was undertaken by 12 ITI unions. The number seems very low considering the existing needs (Beauchamp et al. 2018).

\section{Conclusions and recommendations}

The analyses evidently show that ITI unions believe that the strength of functional areas in the future will be determined by: new buses and trams (with the lack of park\&ride parking lots

equipped laboratory are luxury in Polish schools. Results of the audit by the Supreme Audit Office show that $40 \%$ of district self-governments had difficulties with providing appropriate conditions and infrastructure for vocational education (System szkolnictwa..., 2016).

8 Polish nurseries have a capacity of approximately 100,000 places, but in the majority (71\%) of communes, particularly rural ones, no nurseries operate. In 2016/2017, the overall rate of participation in preschool education for 3- to 5-year-olds was $81.1 \%$, varying from $67.1 \%$ for 3 -year-olds to $90.7 \%$ for 5-year-olds. Preschool institutions were still attended by a much larger proportion of children in urban areas $(88.0 \%)$ than in rural areas $(71.6 \%)$ (The system..., 2018). 
they will be of no use), public buildings covered in styrofoam (but not e-administration), and new education programmes for pupils (but without investments in modern equipment and facilities in schools). This suggests that the ITI tool is a "lens" accumulating influences of the previous programming period, when LGUs gained experience in writing applications and implementing some types of projects, including thermomodernisation, the purchase of public transport fleet, and particularly the organisation of training and courses, usually performed by external companies selected in a tender with the lowest price constituting the leading criterion (the quality of such training is often very low). In the aspect of building a competitive advantage of FUAs, this seems to suggest the short-sightedness of ITI beneficiaries.

These (sad) conclusions lead to proposing several recommendations of what should be changed in the financial and strategic programming as well as in the institutional and governance aspect for the implementation of ITIs to be more effective and not lead to the dispersal of resources in the future.

Financial and strategic programming aspect. Combining programmes, funds, and priority axes in a single project is a good solution. Practice showed, however, that it is not always an effective tool in counteracting wasting of resources. In order to prevent it, firstly, strategic projects should be consulted with the provisions of ROPs (see below), and secondly, a system of data migration on the projects implemented in all programming periods so far should be developed. The determination of directions of intervention also remains problematic. According to the conducted analyses, a major portion of resources will be consumed by the development of education programmes, which is of no substantial use without relevant equipment and facilities in schools. A selection of projects should be performed in terms of actual integration that will translate into the effectiveness of measures.

The analysis of the period of the approval of ROPs and ITI strategies shows that in all cases, the designation of ITI projects and the determination of the rules of their financing could not occur at the stage of ROP development. Due to this, allocations for particular projects and ITI measures were introduced to the already approved ROP.
Such a situation should not repeat in the future programming period. To prevent this, it is necessary to develop ITI strategies and ROP assumptions simultaneously.

Institutional and governance aspect. The management of functional areas implemented by ITI unions has considerable consequences for the territorialisation of interventions. The ITI union overtakes the tasks related to the implementation of the national or regional operational programme which have been so far the responsibility of regional authorities, which means that regions cease to be the only entities and partners for the government regional policy. This, however, generates certain challenges for the future. ITI implementation requires efficiency and cooperation of institutions responsible for the governance and implementation of particular operational programmes. Due to this, ITI unions should have powers broader than just the designation of strategic projects. Having the competence of managing authority for conducting the full procedure of open call for proposals, ITI unions could contribute to the development of FUAs in a more efficient and responsible way .

The most important aspect of the functioning of ITI unions seems to be the cooperation of cities/communes of the functional area exceeding the barriers of administrative borders in programming the functional development of an urban area and its governance, including the organisation of many governing functions covering an urban complex as a functional area. Considering that the binding provisions of ministry documents provided self-governments with the possibility of the establishment of partnerships and the governance of financial resources on a voluntary basis and many cities and communes took advantage of it, it should be highlighted that ITIs support (with more or less success) the promotion of the partnership model of cooperation between different administrative units at functional urban areas in the management of EU funds. ITIs 'forced' the majority of LGUs out of the sphere of declarations and arrangements (usually with no practical consequences), and 'moved' them to the sphere of specific activities. Because ITI has become a 'laboratory' of intercommune cooperation, in the future programming period, the existing FUAs in their current boundaries should be the base on which the intervention concentrates. 
New ministry guidelines and legal acts should grant ITI unions powers to decide on who should or should not participate. The maintenance of flexibility of activities in the scope, without imposing artificial boundaries of the area of intervention, seems to be of key importance in the scope of governance of ITI implementation in the future.

In the majority of cases, the establishment of ITI unions was based on two models of territorial governance in the ITI implementation, namely: 1) the 'interim' model, usually taking form of an arrangement, in which an LGU established an ITI union for the purpose of expending allocations from a ROP (OP IE and OP EP); 2) the 'cooperation' model, where the ITI union is a natural continuation of previously commenced cooperation; usually taking form of an association (Kociuba 2017). It is difficult to determine which of the models proves more effective, but considering the current contracting of ITIs under ROPs, ITI unions functioning in the form of associations show better results. Due to the experience of unions gained in current cooperation, it is desirable to offer freedom in the scope of formalisation of partnerships in the new programming period, whereas it should be possible to change the legal form of partnership based on request of the interested ITI union throughout the period of the tool implementation.

\section{References}

Barca F., 2009. An agenda for a reformed Cohesion Policy, A place-based approach to meeting European Union challenges and expectation. Independent Report for DGRegio, European Comission, Brussels.

Barca F., McCann P., Rodríguez-Pose A., 2012. The case for regional development intervention: Place-based versus place-neutral approaches. Journal of Regional Science 52(1): 134-152.

Beauchamp M., Krysztofak-Szopa J., Skala A., 2018. Polskie startupy. Raport 2018 (Polish startups. Report 2018), Fundacja Startup Poland, Warszawa.

Binek J., Opravil Z., Chmelar R., Svobodova H., 2016. Cooperation and mutual relationships of cities and their hinterlands with regard to the operation of EU integrated development instruments. Quaestiones Geographicae 35(2): 59-70.

Camagni R., Capello R., 2015. Rationale and design of EU Cohesion Policies in a period of crisis. Regional Science Policy \& Practice 7(1): 25-47.

CEC 2012. Elements for a Common Strategic Framework 2014 to 2020 the European Regional Development Fund the European Social Fund, the Cohesion Fund, the European Agricultural
Fund for Rural Development and the European Maritime and Fisheries Fund. Part I. Commission Staff Working Document. SWD(2012) 61. Final, 14.3.2012. Commission of the European Communities, Brussels (accessed: 10 May 2018).

Chłoń-Domińczak A., Dębowski H., Holzer-Żelażewska D., Maliszewska A., 2016. Vocational education and training in Europe - Poland. Cedefop ReferNet VET in Europe reports (accessed: 18 October 2018).

Churski P., Kociuba D., Ochojski A., Polko A., 2017. Towards policy-place-based policy and smart specialisation. In: Kopczewska K., Churski P., Ochojski A., Polko A. (eds), Measuring regional specialisation. New approach. Palgrave Macmillan. Springer: 267-380.

Europe 2020. Strategy for intelligent and sustainable growth promoting social inclusion. Commission Communication, Brussels, 3.3.2010, COM(2010) 2020 final. Online: www.ec.europa.eu/eu2020/pdf/1_PL_ACT_part1_ v1.pdf. (accessed: 26 May 2018).

European Commission. Integrated Territorial Investment, 2014. Online: http://ec.europa.eu/regional_policy/ sources/docgener/informat/2014/iti_en.pdf (accessed: 6 May 2018).

European Commission. Education and Training Monitor 2016. Poland. Online: https://ec.europa.eu/education/ sites/education/files/monitor2016-pl_en.pdf (accessed: 20 October 2018).

Farole T., Rodríguez-Pose A., Storper M., 2011. Cohesion Policy in the European Union: Growth, geography, institutions. Journal of Common Market Studies 49(5): 1089-1111.

Gonciarski W., Mazurek I., 2014. E-administracja w Polsce - główne założenia, stan aktualny i kierunki rozwoju (E-administration in Poland - main assumptions, current status and directions of development). Nowoczesne Systemy Zarzadzania 9(1): 263-290.

Gorzelak G., 2014. Wykorzystanie środków Unii Europejskiej dla rozwoju kraju - wstępne analizy (Application of European Union funds for country development - preliminary analysis). Studia Regionalne i Lokalne 3: 5-25.

Kaczmarek T., Kociuba D., 2017. Models of governance in the urban functional areas - policy lessons from implementation of Integrated Territorial Investment (ITI) in Poland. Quaestiones Geographicae 36(4): 51-68.

Kociuba D., 2017. Zintegrowane Inwestycje Terytorialne jako narzędzie zarządzania terytorialnego w miejskich obszarach funkcjonalnych (Integrated Territorial Investments as a tool of territorial governance in functional urban areas). Studia KPZK PAN 174: 144-153.

Kociuba D., 2017a. Delimitacja miejskich obszarów funkcjonalnych ośrodków wojewódzkich w realizacji Zintegrowanych Inwestycji Terytorialnych $\mathrm{w}$ Polsce - teoria versus praktyka (Delimitation of functional urban areas of voivodeship centres in Poland - theory vs. practice). Studia Regionalne i Lokalne 3(69): 54-78.

Kociuba D., Matacz A., 2018. The real estate market in the context of municipal management. Example of the Lublin functional area. Barometr Regionalny. Analizy i Prognozy 16(1): 67-80.

Kociuba D., Szafranek E., 2018. New tool for measuring sustainable development in functional urban areas. European Spatial Research and Policy 25(2): 61-79.

Kryteria delimitacji miejskich obszarów funkcjonalnych ośrodków wojewódzkich (Delimitation criteria of functional urban areas of voivodeship centres), 2013. Ministry of Regional Development, Warsaw. 
Leipzig Charter on Sustainable European Cities, 2007.

Markowski T., 2013. Territorial dimension of integrated development policy - Expectations and challenges concerning planning and institutional systems. Studia Regionalia 35: 51-64.

McCann P., Ortega-Argilés R., 2013. Some practical elements associated with the design of an integrated and territorial place-based approach to EU Cohesion policy. In: Crescenzi R., Perocco M. (eds), Geography, institutions and regional economic performance. Springer, New York: 95-118.

Mendez C., 2012. The Lisbonization of EU Cohesion Policy: A successful case of experimentalist governance? European Planning Studies 19(3): 519-537.

Mendez C., 2013. The post-2013 reform of EU Cohesion Policy and the place-based narrative. Journal of European Public Policy 20(5): 639-659.

OECD 2001. Territorial outlook, Paris.

OECD 2009. Regions matter: Economic recovery, innovation and sustainable growth. Paris.

OECD 2011. OECD Regional outlook: Building resilient regions for stronger economies. Paris.

Regulation (EU) of the European Parliament and of the Council No 1303/2013 of 17 December 2013 laying down common provisions on the European Regional Development Fund, the European Social Fund, the Cohesion Fund, the European Agricultural Fund for Rural Development and the European Maritime and Fisheries Fund and down general provisions on the European Regional Development Fund, the European Social Fund, the Cohesion Fund and the European Maritime and Fisheries Fund and repeal Council Regulation (EC). No $1083 / 2006$

Regulation (EU) of the European Parliament and of the Council No. 1301/2013 of 17 December 2013 on the European Regional Development Fund and the specific provisions concerning the Investment for growth and jobs goal and repealing Regulation (EC). No 1080/2006.

Regulation (EU) of the European Parliament and of the Council No 1304/2013 of 17 December 2013 on the European Social Fund and repealing of Council Regulation (EC). No 1081/2006.

Pietrzyk I., 2004. Polityka regionalna UE $i$ regiony w państwach cztonkowskich (EU regional policy and regions in the member states). Wydawnictwo Naukowe PWN, Warszawa.

Rodríguez-Pose A., Fratesi U., 2002. Between development and social policies: The impact of European Structural Funds in objective 1 regions. Regional Studies 38(1): 97113.

Storper M., 1997. The regional world. Territorial development in a global economy. The Guilford Press, New York.

Szafranek E., 2015. Cohesion of planning and programming the development of regions in the conditions of a territorially-oriented policy. Studia Regionalia 41-42: 169-184.
Szlachta J., Zaucha J., 2012. For an enhanced territorial dimension of the cohesion policy in Poland in the 2014-2020 period. Instytut Rozwoju, Sopot.

Śledziewska K., Zięba D., 2016. E-administracja w Polsce na tle Unii Europejskiej. Jak z niej (nie) korzystamy (E-administration in Poland against the background of the European Union. How we (do not) use it). Digital Economy Lab UW, Warszawa.

Śleszyński P., 2013. Delimitacja miejskich obszarów funkcjonalnych stolic województw (Delimitation of the urban functional areas of voivodeship capitals). Przeglad Geograficzny 85(2): 173-197.

System Szkolnictwa Zawodowego. Informacja o wynikach kontroli (Vocational education system. Information on audit results), 2016. Najwyższa Izba Kontroli, Warszawa.

Territorial Agenda of the European Union 2020: Towards an inclusive, smart and sustainable Europe of diverse regions, 2011. Agreed at the Informal Ministerial Meeting of Ministers responsible for Spatial Planning and Territorial Development on 19th May 2011. Gödöllő, Hungary.

The System of Education in Poland 2018, 2018. Kolanowska E. (ed.), Foundation for the development of the education system, Warsaw.

Tödtling F., Trippl M., 2005. One size fits all? Towards a differentiated regional innovation policy approach. Research Policy 34: 1203-1219.

Treaty of Lisbon amending the Treaty on European Union and the Treaty establishing the European Community, signed at Lisbon, 13 December 2007, OJ C306, 17.12.2007.

Umowa Partnerstwa (Partnership Agreement) 2014. Ministry of Infrastructure and Development, Warsaw.

Urban Agenda for the EU 'Pact of Amsterdam' Agreed at the Informal Meeting of EU Ministers Responsible for Urban Matters on 30 May 2016 in Amsterdam, The Netherlands. Online: http://www.eukn.eu/fileadmin/Files/EUKN_ Documents/05_Paper_1_.pdf (accessed: 15 May 2018).

van der Zwet A., Miller S. and Gross F., 2014. A first stock take: Integrated territorial approaches in Cohesion Policy 2014-20. IQ-Net Thematic Paper 35(2). European Policies Research Centre, University of Strathclyde, Glasgow.

van der Zwet A., Bachtler J., 2018. New implementation mechanisms for integrated development strategies in ESIF, EStIF 1:3-12.

Zasady realizacji Zintegrowanych Inwestycji Terytorialnych w Polsce (Principles for the implementation of the Integrated Territorial Investment in Poland) 2103. Ministry of Regional Development, Warsaw.

Zasady uwzględniania wymiaru miejskiego polityki spójności UE, w tym realizacja Zintegrowanych Inwestycji Terytorialnych (Principles of accommodating the urban dimension of the EU's Cohesion Policy, including Integrated Territorial Investments) 2013. Ministry of Regional Development, Warsaw. 